\title{
Historein
}

Vol 7 (2007)

History and Utopia

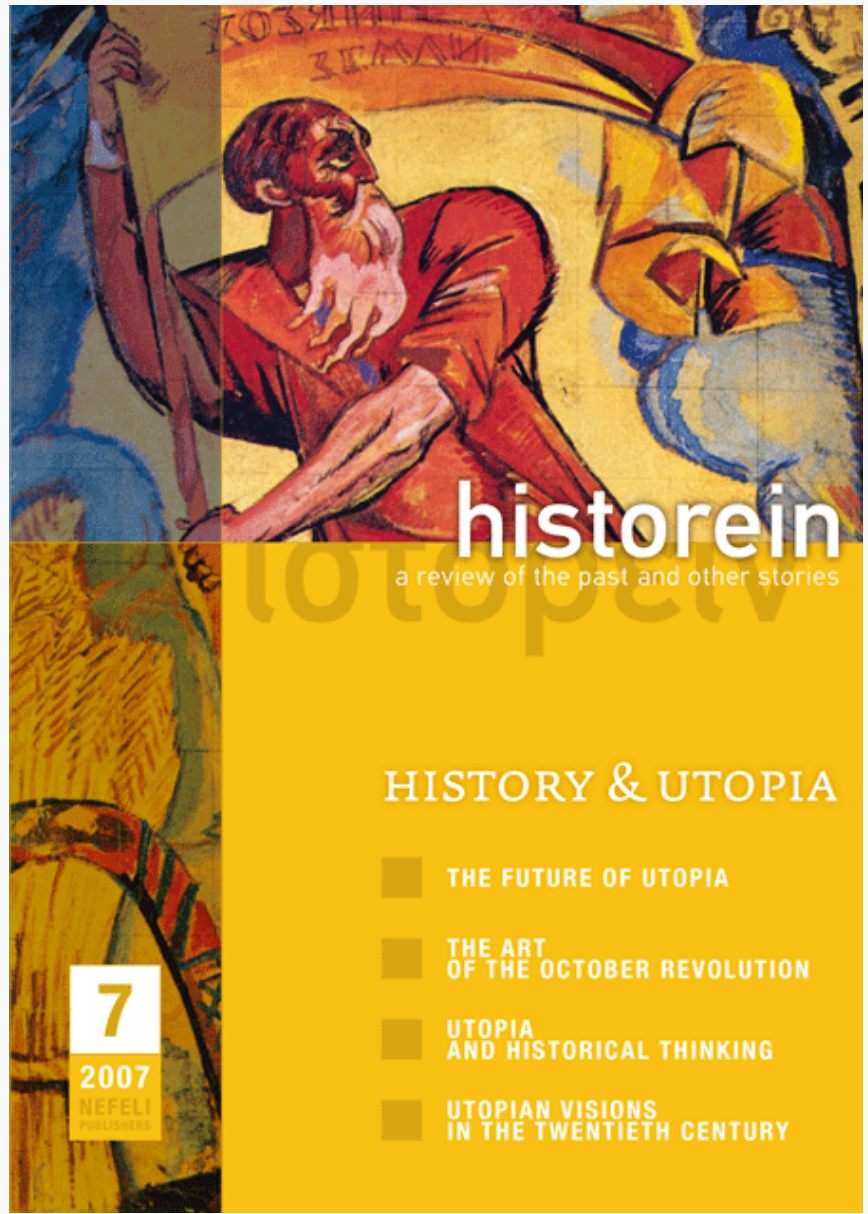

\section{The Future of Utopia in History}

Hayden White

doi: $10.12681 /$ historein.48

Copyright (c) 2012, Hayden White

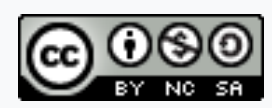

This work is licensed under a Creative Commons Attribution-NonCommercialShareAlike 4.0.

\section{To cite this article:}

White, H. (2008). The Future of Utopia in History. Historein, 7, 12-19. https://doi.org/10.12681/historein.48 
Discussions of the topos of utopia have typically featured the alleged antipathy between utopia and history. "[H]istory", Lewis Mumford said, "is the sternest critic of utopias." Mumford meant, of course, that history - the actual course of events - always proves the impossibility of utopias. Utopia suggests the transcendence of the conditions obtaining at a specific time and place, and in that degree the utopian project is doomed. This formulation makes sense for the modern period in the West but only insofar as the term "history" has come to be used to designate a reality lived differently by different groups of men in specific time, place, and structural social configurations. "History" is a congeries of "places" (topoi) which, while originating in and growing out of "nature", are nonetheless distinguishable from this nature by the system of controls and constraints they posit as necessary and/or desirable for the living of a specifically human (as against an animal) life. As a "non-place" (atopos), utopia is anything but historical. Whence Mannheim's famous invocation of "history" as providing the criterion by which to distinguish between two kinds of "situationally transcendent" or simply "unreal" ideas: ideological, on the one hand, and utopian on the other.

"In the course of history", Mannheim writes, "man has occupied himself more frequently with objects transcending his scope of existence than with those immanent in his existence." Indeed, "[e]very period of history has contained ideas transcending the existing order, but these did not function as utopias; they were rather the appropriate ideologies of this stage of existence as long as they were 'organically' and harmoniously integrated into

\section{The Future}

of Utopia

\author{
in History
}

\section{Hayden White}

Stanford University 
the world-view characteristic of the period (i.e. did not offer revolutionary possibilities). ${ }^{{ }^{3}}$ As long as every imagined paradise was located outside of society, "in some other-worldly sphere which transcended history and embodied these wish-images into their actual conduct, and tried to realise them", these ideas remained only "ideological". They might function as paradigms of ideal activity by which to judge comportment in everyday life, they might even serve as a kind of blueprint for human aspiration, or even be used to justify reforms and revisions of inherited social systems, but as long as they remained thus sublimated, as ideals never meant to be fully realised in real life, then such ideas remained "ideological". Only when "certain social groups embodied these wishimages into their actual conduct, and tried to realise them, did these ideologies become utopian". What made them "utopian", in Mannheim's estimation, was that they were "incongruous", not with "existence as such" but with the "concrete historical form of social existence" obtaining at a given time and place. It is the difference between "existence as such" (which is a problem "that belongs to philosophy and is of no concern" to Mannheim) and "a concrete historical form of social existence" that provides Mannheim with the criterion for deciding what is "realistic" and what is not in both ideologies and utopias.

What I want to dwell upon for a moment is the confidence with which Mannheim postulates the "historically or sociologically real" as the "reality" against which the relative realism of ideologies and utopias, as well as political and social thought in general, is to be measured. He says,

[W] hat is to be regarded as 'real' historically or sociologically at a given time is of importance to us and fortunately can be definitely ascertained. For the sociologist, 'existence' is that which is 'concretely effective', i.e. a functioning social order, which does not exist only in the imagination of certain individuals but according to which people really act. ${ }^{5}$

Mannheim goes on to distinguish between a "historical" concept of "history" and the many other approaches to the study of social events, processes, and structures offered by other social sciences: “... we may expect that the historian will criticise our definition of utopia as too much of an arbitrary construction because, on the one hand, it has not confined itself to the type of works which got their name from the Utopia of Thomas More, and on the other because it includes much which is unrelated to this historical point of departure".

Now, a great deal of the criticism directed at Mannheim's path-breaking book, Ideology and Utopia, fixes upon his supposed misrepresentation of the history of ideology (and utopia). Judith Shklar has written that:

To understand why the classical utopia declined, not yesterday, but almost two hundred years ago, demands a more detailed analysis of its character than either Marx. Engels, or Mannheim offered. It also requires a return to that historical way of looking at the past which they despised, because it does not try to uncover 'real' patterns, not to establish laws. ${ }^{6}$

In this essay, I want to reflect with you on this topos which sets utopia over against history as fantasy against fact, as the pleasure principle versus the reality principle, as myth against reason. But not in order to criticise utopianism for failing to pay its debts to history, but on the contrary to challenge the 'party of history' for its repression of the utopian moment in history's own makeup and for casting it out of any properly historical reflection on history as a residue either of infantile self- 
indulgence or of senile imbecility. To put it in the postmodernist idiom, I want to consider history as utopia's Other rather than the reverse, and ask what has been lost in our understanding of that history that is supposed to be the ground and measure of a specifically modernist brand of realism which, against all reason, has brought us to the dystopian situation in which the earth itself is under threat by the very instruments of science, technology, and political economy that were supposed to save it for human use and enjoyment. And this not only because it is commonly thought that, as Lewis Mumford, a great historian of utopias, put it: "... history is the sternest critic of utopias", " that "history" in its reality always undermines and explodes the utopian dream world, but because "history" itself has turned out to be that nightmare from which we cannot awaken and, more importantly, turns out to offer very little in the way of understanding our present situation or helping us to escape it.

To say that utopia is now history is, of course, ironic in a context in which it is believed that the principal reason that utopia is now history is because utopia is in some sense history's "Other", by which we mean, not only the opposite of "the past" and a repudiation of that "temporal process" by which and in which the present becomes past, but also a rejection of the kind of knowledge that is supposed to be attainable by a proper kind of "historiological" reflection on this process. But utopia is history's Other in another sense as well - in the sense of being an expression of a memory of a repressed desire, in this case, a desire for the future or rather a future against the claims of a social system which forbids us both to want a future different from our present and at the same time urges us to see in the present social dispensation the future which has already arrived and of which we ought not want better.

Many of the dream-plans of community that are called "utopias" are based on nostalgia for real or imaginary past worlds and express or reflect a melancholic unease with the present. But these are to be distinguished from the future-oriented utopias of modernity, in which the relation between the present and the past is mediated by a promise-fulfilment model of generational affiliation rather than by a potentiality-actualisation model common to Hegel, Marx, the progressivist historians and historical school avatars, all at once. Karl-Heinz Bohrer makes a distinction between historical mourning ("historische Trauer"), which is a longing for a past we never had, and poetic mourning ("poetische Trauer"), which is a longing for something we cannot live without. Bohrer believes - or once believed - that it is poetic mourning which informs the distinctively modern (post-Romantic) sense of "presentness" characteristic of aesthetic nihilism. This permits him to forbid any talk of a "poetics" of "history" on the basis of which one might envision a future at once continuous with and disjoined from the past in a relationship of appropriation and sublimation at one and the same time.

Modernist utopias are temporal - in the way that the Christian apocalypse and millennium are temporal - but are material, bodily, immanent, and this worldly rather than spiritual, soulful, transcendental and other-worldly, like their Jewish and Christian prototypes. Of course, it is commonly thought that utopian thinking is a secular version of Christian apocalyptical thinking and that utopians are people who hope to be "enraptured" and "swept up", "in the twinkling of an eye" "transported" either to Heaven or some version of the Promised Land. But modernist utopia is rather more metamorphic than apocalyptical: it envisions the kind of transformations worked by the gods on 
men in Ovid, changes in the attributes of a thing without a change a substance. But with this twist: since modernists do not believe in the distinction between the substance and the attributes of things, they regard a change in appearances as tantamount to a change in substance. In fact, the modernist utopia envisages a humanity in which the aim of human species development is to shed the illusion of substance (and substantiveness) altogether and thereby heal the pain caused of the principium individuationis by abduction. This distinction can help us understand the peculiar attitude towards time and history in artistic modernism which, wherever it appears, rejects not so much "history" as all the ideas of history inherited from the nineteenth century, whether from Hegel and Marx or from Ranke and Droysen, and their recent avatars, whether the practitioners of professional historiography (which locks thought about time and history within the narrow relationship of present and past or past to present, sternly repressing any thought about the future of our own present time and even any idea that a knowledge of this future on the basis of historical knowledge might be possible) or Bohrer's "aesthetic nihilists" who take pleasure in the knowledge that neither past nor future can match the "thrill" of "suddenness" and intimations of catastrophe.

Much has been made of literary modernism's rejection of history and the historical - of Pound's, Eliot's, Woolf's, Kafka's, Proust's, Joyce's, Svevo's, and Musil's wholesale “flight from history" and into a Schellingian or Heideggerian night in which all cows are black, their supposed "celebration" of the irrational and the uncanny, their abandonment of narrative coherence, their substitution of a fascination with the spectres of memory at the expense of the knowledge provided by "history", all as a way of putting the modernists to the side of the development of a brand of "realism" that was supposedly the sole organon of a progressive and enlightened path to a democratic, socialist, or, failing that, at least a liberal future. Literary and aesthetic modernism is supposed to have been enamoured of the Proustian swimming in a dark ocean of involuntary memory where the anxieties of everyday life under capitalism can be anesthetised by fantasies of Sadean perversion and Huysmans-like longueres. But this is to misunderstand the profundity of modernism's critique of the banalities of realist historicism. Above all historicism's foreclosure of any future other than that of the same old bourgeois thing - Benjamin: "The catastrophe would be if things stayed the same." The modernists felt that they had inherited a landscape engorged with ruins of a once vital but essentially barbarised culture - of a barbarism rendered more barbaric (Vico) by virtue of its possession of a science whose power could be turned to any purpose, constructive or destructive, as the case might be. Inheriting a landscape of ruins, the modernists correctly perceived that the problem was to discriminate between what was broken but still useful and what was both broken and, as it were, contaminated, in the way a nuclear test site is contaminated, with waste products that could neither be used nor disposed of without dire risk. The problem was to use these ruins, this waste, these monstrous hybrids and garbage, to build a future that would not resemble the burnt-out landscape and crash-derby mayhem depicted in the Mel Gibson epic, Mad Max 2: Road Warrior.

It was not that the modernists denied the possibility of a future. It was that they recognised how difficult it would be to build a future out of the stuff that had been left to them in the form of a historical legacy that was as insubstantial as it was glossy and that had been packaged to flatter the very servants of power and wealth who had had eviscerated Western culture precisely by living up to its ideals. 
Antiquarian "utopias" are not anti-historical; they serve to inspire such sublimative practices as professional historical research, archaeology, antique collecting, all of the restorative disciplines and the whole historical museum industry, not to mention the so-called "heritage" movement and Disneyesque historical "theme parks". These should not be confused with what I wish to call "modernist utopias" which come into being contemporaneously with modernity itself, by which I mean "our modernity", the modernity caused by a fully-developed, global capitalism which expropriates and absorbs every tradition from our own past and, where the market requires it, the pasts of others. This brand of capitalism sweeps away even the remains of an earlier, commercial and industrial capitalism, with their firms linked to the destinies of specific nations, regions, and even neighbourhoods of the industrial cities and in which a craft-like "look" of a commodity could increase its value. Now all vestiges of both an older crafts world and a somewhat younger "industrial" manufactory, one that still bore the marks of human as against robotic or machine labour, have been relegated to the dustbin of "collectibles" or the museums of industry and technology, whose aim is to promote an interest in the past that will not deflect attention from the present as presenting all the possibilities of need satisfaction.

It is ironic, of course, that I should be able to say, if only in quotation, that "utopia is history", because if there is one thing on which everyone agrees, it is that utopia is not, it is "history". Indeed, it is a conceit of modernity that utopia is radically anti-history, is impelled by a desire to "get out of history", to either escape the burden of historical existence by returning to a condition of Edenic bliss or to dream of a time and place where the kind of change identified as specifically historical has come to an end, time itself is, as it were, abrogated, politics has been rescinded, and people are permitted to become persons fully without having to undergo the kind of tutelage that modernity was instituted to depose. To be sure, here the word "history" is understood to mean precisely that mode of human existence in which the most arduous and creative forms of human labour cannot possibly result in the achievement of a human community characterised by both "law and order" and "peace and plenty" of the kind envisioned as utopia. Since the early nineteenth century, utopia has been conceived as the antithesis of history: where there is history, there is no utopia; where there is utopia, there is no history.

In the early nineteen-sixties, in a symposium sponsored by the American Academy of Arts and Sciences (entitled: Utopias and Utopian Thought: A Timely Appraisal), ${ }^{8}$ the symposiasts generally agreed that utopian thinking was a poor after-effect of a longing for deliverance that was essentially religious or mythical, a manner of thinking which had long since been discredited not only philosophically but also practically by history. A distinguished anthropologist opined that in the best of cases, utopia could mean only "liberation of man's higher faculties" and the aspiration to the "contemplative life". Those utopias which focussed on the human body and its needs and desires and envisioned a life of play, "leisure and abundance", he said, were not only childish but "built on forgetfulness". "What [utopia] forgets", George Kateb wrote, "is history", which he immediately glossed as "the record of human suffering". "What it tries to forget", he went on, "is mortality."

Utopia tries, apparently, to forget a great deal more as well. Judith Shklar follows the modern doxa on utopia by tracing its anti-historical bent to its origins in religion and metaphysics. Commenting on the archetype of modernist utopian reflection, Sir Thomas More's Utopia, Shklar holds that 
its "Utopia" is inherently anti-historical. She points out that in More's fable, the founder "Utopus' simply appears one day and creates utopia". ${ }^{10} \mathrm{He}$ arrives trailing no origin or past; and his creation does not base its claims to legitimacy on genealogical affiliations with ancestors. The "present" of Utopia is no "heritage" passed down from the past to the present as a precious legacy, to be carried forward, cultivated, and made to grow (Heidegger). And because Utopia is anti-historical it is also, in Shklar's judgement, "profoundly radical". For according to Shklar, what utopia wishes to bring under judgment and what it finds "utterly wanting" in real life is nothing less than "all historical actuality" when utopia brings it before "the bar of trans-historical values". It is this trans-historicality that blinds utopia to the reality of a genealogical tie with the past, and it is this blindness that makes it "profoundly radical" in its essence.

I take it that the challenge to inquire into the future of utopia or the future of utopian thinking, the effort to think of the possibility of radical change in our condition or our situation, in which a rogue state (the United States government of George Bush) shows the power to push the world towards a nuclear war, in which a country pursuing the imperatives of a capitalist system gone amuck with the desire to consume has created a veritable "culture of the death drive", in which the very effort to think of change must labour under the spectres of heat death, environmental depletion, nightmares of drowning in waste, and of a life lived on the garbage dump - all this might foreclose our impulse even to imagine, let alone wager on ,the possibility a better world for our children and their progeny.

We are told by certain self-described realists of the Left that the fall of the Soviet Union definitively disconfirmed the communism they had once devoutly and even heroically defended. And so too we are told this by those realists of the Right who presume that the victory of the West in the Cold War not only confirms the validity of capitalism as the sole possible way of life from now on but also invalidates any belief in the desirability of a thought that would go beyond the present and dare to think a future beyond the orgy of consumption and waste called advanced capitalism or "the free market economy". Those of us who believe that fundamental changes in our social system - by which I mean, of course, the capitalist social system - are not only desirable but are also necessary for survival are now told that we are crazy if not criminal, that, in a word, we are, well, utopians.

Apparently, it is OK to try to imagine all kinds of dystopias, wastelands in what is now called in the US "the homeland", and fantasise worst-case scenarios of the kind daily produced by the US Department of Justice, the FBI, and the CIA, in order to justify massive expenditures in arms, military, mercenary, and police forces to protect the citizens from the dangers offered by the new universal and all-purpose enemy: the terrorist. These fantasies are produced by the establishment and disseminated by the media to keep the war machine and the arms industry running, fuel the financial institutions of globalised society, and keep the fate of democracy linked to the future of the "free market economy". But to dare to suggest that we can foresee a time and a condition that would allow us to shut down the war machine itself, is, in my country at least, treated as both utopian and tantamount to treason.

As I surveyed the literature on and about "utopia" in preparation for this article, I was depressed by the consistency with which all of the custodians of "the reality principle", the cultivators of that "re- 
alism" which is commended to us as the only possible "real place" from which our thought about our present and its possibilities of becoming a future should be launched, were agreed that "utopian thinking" was and had to be considered to be mere fantasy, "wishful thinking", delusion, dream, or opiate. Utopia, even modern utopia, the realists of our time tell us, belongs at best to the past, specifically the recent past, more specifically the period beginning with the transition from feudal to capitalist society and extending up to our present. Earlier, medieval and ancient manifestations of the desire for redemption are less than properly utopian insofar as they presuppose an otherworldly dimension, beyond time, space, and materiality, in which humanity, finally alienated from its place of alienation, can at last find peace and rest.

It is otherwise with modern utopias. Modern utopias are born of a reaction to modernity itself. Although this reaction may take the form of an idealised vision of what once had been (pastoral or peasant life, the life of the village, the tribe, or the ethnos still connected to nature), it is still impelled to take this bit of redeemed past and "make it new" or re-make it (re-birth it) so as to accommodate it to desires and/or anxieties of a recognisably "modernist" kind. Here I am thinking of the utopian vision that informs Ernst Bloch's putatively "modern" study of utopia itself: Das Prinzip Hoffnung [The Principle of Hope] is a work which manifests all of the symptoms of the illness which it sought to cure. Bloch was disgusted by modernity, but his book is redolent of a desire for what it despises. And this is true of all modern utopias. Modern utopias want to escape not the real world, materiality, or history, but rather that version of these things that we call "modernity" itself. This is in accordance with the principle, stated by Fredric Jameson, that each historical period has its own utopia. Consequently, it is important to recognise that if we are asking about the future of utopia, we are also asking about the future of the historical period or chronotope - that modern period that we inhabit as our present.

Modern utopia seeks escape from modernity, which is one reason why modern utopia is discontinuous with its earlier, religious and mythical prototypes. The term names a symptom of a specific historical period, namely, those brands of socialism of the nineteenth century, their "extremist" avatars in the twentieth century which dared to imagine a world that improved upon the techno-capitalist present: the fanatics, the terrorists, the dreamers, the opiated representatives of an earlier, mythic consciousness. This literature, while granting that utopian thinking during the process of Western civilisation's transition from feudal, peasant, and pre-industrial society to capitalist, bourgeois, and post-industrial society, served as an effective and even beneficial instrument (means) of progressive innovation - bourgeois utopianism was a good thing, inspiring the agents of social change to the sacrifice necessary to bring about the bourgeois dispensation - this literature about utopian thinking now informs us that this mode of thinking is no longer necessary or that, in respect to the realities of this dispensation, which is our reality, is hardly conceivable much less possible as an instrument of our liberation from the "discontents", das Unbehagen, of our social, cultural, and political moment. In a word, in our time, utopian discourse, the discourse of "what might be" and "what ought to be" - in contrast to the discourse of "what is", "what is the case", reality, the real, things as they are, etc. - this discourse we are told is not only no longer desirable, it is not, from the standpoint of that instrumental reason which prevails in our social sciences, even possible. Except, of course, as dream, nightmare, reverie, delusion, sop for the necessary and unavoidable casualties of a modernity that is our fate, our 
destiny, our telos, end, aim and purpose in life, the condition to which we are indentured for "the time that remains", the condition to which all of the other peoples and cultures of the earth are condemned to aspire, whether they wish it or not, if they wish to survive and "develop".

My thesis, then, is this: that modern utopian thinking and its various versions of both theory and practice are of a piece with the rise of the idea of history as a distinctively human mode of being in the world, such that we must consider the possibility that what we mean by "utopian" thinking must be viewed as characterised by a resistance to accepting "history" as defining a specifically human kind of being in the world and historical knowledge or a knowledge of history as the criterion for determining what can count as the criterion for deciding what is realistic and what is unrealistic in any given proposal for a utopian alternative to the lived reality of a specific time and place in human being. If "history" is "reality", if historical knowledge tells us what is real and how this reality came to be what it is and in telling this also establishes its necessity and sets limits on what it is possible to do in and against this reality, then it follows that any utopian project seeking to liberate us from this reality will be adjudged to be "unrealistic", precisely in the degree to which it is "unhistorical". I am reminded of Freud's argument in Das Unbehagen in der Kultur [Civilisation and Its Discontents], namely, that if civilisation itself is the cause of the specific illnesses from which we are suffering, then it is delusory to think that more "civilisation" of this kind could cure this malady. So, too, if it is "history" from which we are suffering, then it is foolish to think that more "historical knowledge" could liberate us or cure of this malady of "historicity". If, as Joyce's Stephen Dedalus tells us, history is that "nightmare" from which we are trying to awaken, then it is foolish to appeal to this "history" as an antidote for the utopian projects that are intended to liberate us from it.

Now, this gives us a way not only of distinguishing between progressive and regressive utopias - in the degree to which they affirm or reject knowledge of history as the instrument for justifying the realism of their projected alternatives to "reality" - but also for justifying utopian projects precisely insofar as they take history as naming the condition they wish to transcend. This allows us also to account for the utopian appeal of Francis Fukuyama's school-boyish exercise in a philosophy of history which proclaims "the end of history". For it is obvious that what Fukuyama proclaims is a way of saying that America (by which he means capitalist society of the American kind) is the realisation of the only utopia that can be realistically envisaged as having been fully realised in fact as well as having been dreamed of in imagination. The American way of life, as it is called, is utopia realised in reality. And its victory over its modern and ancient alternatives - the fascist and Nazi and Soviet utopias - confirms both its utopian substance and its transcendent realism as an achieved project that now can look forward only to an immanent development of its concept and its expansion in space - the global space of postmodernity - as a kind of development in place that has nothing "historical" about it.

Popular discourse has absorbed the maxim of the philosopher George Santayana to the effect that: "Those who neglect to study the past are condemned to repeat it." We hear this all the time; it is routinely applied as an admonishment to those societies which have failed in their efforts to chart a future different from their past - as if history itself taught that humanity could only lose by trying to change for the better. Everyone forgets what Hegel said in the Vorlesungen über die Philosophie der Geschichte [Lectures on the Philosophy of History]: "Was die Erfahrung aber und die Geschichte 
lehren, ist dieses, daß Völker und Regierungen niemals etwas aus der Geschichte gelernt und nach Lehren, die aus derselben zu ziehen gewesen wären, gehandelt haben."11

In Ideologie und Utopie [/deology and Utopia], published in 1929, Karl Mannheim had already espied the end of utopian thinking and linked its ending with the advent of a new politics of managers, technicians and intellectuals who, unlike their nineteenth-century predecessors, were "beyond" both ideology and utopia, as they were "beyond" history. Judith Shklar, reflecting on Mannheim's fear that the end of utopia meant something like the end of art and culture of the contemplative and classical kind, suggests that his question "Why are there no utopias today?" is "more a comment on an intellectual situation than a real query". ${ }^{12}$ Shklar held that the fact that there are no utopias today indicates that utopia itself is dead, over and done with, no longer even a possibility for serious thought or, as Americans say when they want to indicate that something is really over, totally over, "utopia is now history".

\section{FOOTNOTES}

1 Lewis Mumford, "Utopia, The City and The Machine", in Frank E. Manuel (ed.), Utopias and Utopian Thought, Boston: Beacon, 1967, p. 12.

2 Karl Mannheim, Ideology and Utopia: An Introduction to the Sociology of Knowledge, trans. Louis Wirth and Edward Shils, New York: Harcourt, Brace, 1946 (1929), p. 173.

3 Mannheim, Ideology and Utopia, pp. 173-74.

4 Ibid., p. 174.

5 Ibid.

6 Judith Shklar, "The Political Theory of Utopia: From Melancholy to Nostalgia”, in Manuel (ed.), Utopias and Utopian Thought, pp. $103 \mathrm{f}$.

7 Mumford, Utopia, p. 12.

8 See Manuel (ed.), Utopias and Utopian Thought.

9 George Kateb, "Utopia the eternal human: Utopia and the good life", in Manuel (ed.), Utopias and Utopian Thought, p. 248.

10 Shklar, Political Theory, pp. $104 f$.

11 Georg Wilhelm Friedrich Hegel, "Vorlesungen über die Philosophie der Geschichte", in Werke, Vol. 12, Frankfurt: Suhrkamp, 1970, p. 17. H. B. Nisbet translates this as: "What experience and history teach is this - that nations and governments have never learned anything from history, or acted upon any lessons they might have drawn from it."

12 Shklar, Political Theory, p. 114. 